Plant Molecular Biology 20: 921-938, 1992.

(C) 1992 Kluwer Academic Publishers. Printed in Belgium.

\title{
Translation controls the expression level of a chimaeric reporter gene
}

\author{
L.A.M. Hensgens ${ }^{1}$, M.W.J. Fornerod ${ }^{2}$, S. Rueb ${ }^{1}$, A.A. Winkler ${ }^{1}$, S. van der Veen ${ }^{3}$, R.A. Schilperoort ${ }^{1}$ \\ ${ }^{1}$ MOLBAS Research Group, Institute of Molecular Plant sciences, Clusius Laboratory, Leiden \\ University, Wassenaarseweg 64,2333 AL Leiden, Netherlands; ${ }^{2}$ Department of Cell Biology and Genetics, \\ Erasmus University, Rotterdam, Netherlands; ${ }^{3}$ Center for Phytotechnology RUL/TNO, Leiden, \\ Netherlands
}

Received 23 April 1992; accepted in revised form 20 July 1992

Key words: $\beta$-D-glucuronidase, mannopine synthase promoter, Agrobacterium, gene expression, initiation of translation.

\begin{abstract}
Transcriptional and translational fusions between the reading frame of the $\beta$ - $D$-glucuronidase gene (gusA) and the $2^{\prime}$ as well as the 1' promoter of mannopine synthase (mas), a $\mathrm{T}_{\mathrm{R}}$ locus of Agrobacterium tumefaciens, were made. The expression of these constructs was studied in the transgenic $F_{1}$ offspring of independent tobacco transformants at the protein level by assaying for GUS activity and western blot analysis of the GUS protein and at the steady-state mRNA level.

In leaves, stems and roots no correlation was found between steady-state levels of GUS mRNA and enzyme activity. In older tissues significantly higher GUS activities were found. This is explained by the stable character of the GUS protein together with an accumulation of protein upon ageing. Three to ten times higher GUS activities were found for in vitro grown plants than for greenhouse-grown plants of the same offspring, despite similar levels of GUS mRNA. Roots from in vitro grown plants display three to ten times higher GUS activities than stems and leaves.

In transgenic plants grown in vitro, containing a translational fusion with two AUGs in phase, the initiation of translation in leaf material occurred at both AUGs. Initiation of translation at the first AUG, however, was ten times more frequent. In contrast, initiation in roots from in vitro grown plants occurred exclusively at the second AUG.
\end{abstract}

\section{Introduction}

In constructing vectors for genetic engineering of plants, much attention is being paid to promoters. Expression levels of chimaeric gene fusions in plants has mainly been studied using the $35 \mathrm{~S}$ promoter of cauliflower mosaic virus (CaMV) [3,, $38,44,47]$ or promoters of genes coding for nopaline synthase or mannopine synthase from the T-DNA of Agrobacterium tumefaciens [27, 51, 52]. The 35S CaMV promoter conferred high expres- sion to chimaeric genes in transgenic dicotyledonous plants [33]. Fusions with different areas of promoters and constructs combining well defined promoter sequences have revealed specific motifs for the regulation of transcription in relation to, for example, tissue specificity as well as enhancer elements [3, 25, 34, 35].

Little attention has been paid so far to the impact of the translational process in transgenic plants. The relevance of the leader sequence has been demonstrated by Gallie et al. [11]. An in- 
creased translation was observed in transient assays when the translational enhancer, $\Omega$, derived from tobacco mosaic virus was present at the $5^{\prime}$ end of the GUS mRNA. Employing the gusA gene Kato et al., [24] showed that the sequence flanking the initiation codon has a great effect in transient assays with rice and tobacco protoplasts. Here we describe different translational and transcriptional promoter fusions with the gusA reading frame and their expression in transgenic tobacco plants.

We constructed three gus $A$ chimaeric genes de novo. The dual promoter fragment belonging to gene $2^{\prime}$ and $1^{\prime}$ of the $T_{\mathrm{R}}$ DNA of the Ti-plasmid pTiAch5 present in A.tumefaciens strain LBA3267 was used as well as the termination sequence from gene $0^{\prime}$. Both transcriptional and translational fusions were introduced in Nicotiana tabacum cv. Petit Havanna $\mathrm{SR}_{1}$ plants. The expression of the transferred genes was studied in the $F_{1}$ progeny at the level of RNA, protein and GUS activity.

The present study reveals that the translational process has a crucial impact on the final level of gene expression, i.e. on phenotypic expression.

\section{Materials and methods}

\section{Construction of binary vectors}

Constructs were made in a modular way. Various parts (promoters, terminator sequences, reading frames and border sequences for transfer of T-DNA) were subcloned in pIC plasmids [28] and then assembled. Complete constructs, carried as a single Hind III fragment on a pIC plasmid, were shuttled to wide - host - range plasmids and crossed to different Agrobacterium strains.

A synthetic left border, corresponding to the octopine right-border repeat was cloned as a $X b a$ I-Sac I fragment into pIC19H cut with $X b a$ I and $S_{s t}$ I [49], yielding the construct plam2. The $\mathrm{T}_{\mathrm{L}}$ octopine right border plus the overdrive sequence were cloned as a $B a m \mathrm{HI}-B c l$ I fragment from pTiAch5 (T-DNA sequence 13774-14711
[1]) into the Bam HI site of pIC19R. A construct was obtained in which the overdrive sequence was close to the $P_{s t}$ I site of pIC19R. From this construct the Bam HI-Pst I fragment was isolated and cloned into plam 2 cut with Bam $\mathrm{HI}$ and $P s t \mathrm{I}$. A construct pLAMA was obtained containing the synthetic left border and the right border and overdrive sequence.

To obtain construct pLAMB, the gusA reading frame was isolated from pBI101.2 as a Bam HI$S a c$ I fragment of which the $S a c$ I site was blunted with $S_{1}$ nuclease. The fragment was cloned into pIC19H digested with Bam HI and Sal I. The $\mathrm{Sal}$ I site was filled in with Klenow.

pLAMC contains the terminator sequences of genes $0^{\prime}$ and $1^{\prime}$ from the octopine $\mathrm{T}_{\mathrm{R}} \mathrm{DNA}$. A 749 bp Pst I-Nla IV (T-DNA sequence 2170722456 [1] fragment isolated from pRAL3267 [38] was cloned into pIC20R digested with Pst I and Nru I,

In clone pLAMD the gusA reading frame was fused to the termination sequence in clone pLAMC. A Bam HI-Pst I fragment from pLAMB was cloned into pLAMC digested with $B a m$ HI and Pst I. The Pst I site in pLAMC was derived from the pIC polylinker.

pLAMF contains the dual promoter of the $T_{R}$ genes $2^{\prime}$ and $1^{\prime}$. The $521 \mathrm{bp} \mathrm{Nla}$ IV-Cla I fragment (T-DNA sequence $20128-20649$ [1]) was isolated from pRAL 3267 and ligated into the Cla I and filled-in Eco RI sites of pIC20H.

The gus $A$ reading frame - $0^{\prime}$ terminator sequence present in pLAMD was fused in several ways to the $2^{\prime}-1^{\prime}$ double promoter fragment. The Sma I-Eco RV fragment from pLAMF was cloned into the Sma I site upstream of the gusA reading frame in pLAMD. In one orientation, the gene $2^{\prime}$ promoter was fused to the gusA reading frame (pLAMG13m). In the other orientation the gene $1^{\prime}$ promoter was fused (pLAM10m). Another gene $2^{\prime}$ fusion (pLAMG271) was obtained by insertion of the Sma I-Cla I fragment from pLAMF ( Cla I site filled in with Klenow) into the Sma I site of pLAMD.

The promoter gusA terminator sequences were shuttled into the border construct pLAMA. pLAMH13m and pLAMH271 were obtained by 
cloning of the Sma I-Eco RI fragment from pLAMG13m and pLAMG271 into pLAMA cut with $E c o$ RI and $E c o$ RV. pLAMH10me was obtained by inserting the filled-in (Klenow) Cla I fragment of pLAMG10me into pLAMA digested with $E$ co RV. In plamH10me the AUG initiation codon of gene 1' is not in phase with the gusA reading frame. One $\mathrm{C}$ was removed from the $K p n \mathrm{I}$ site, 19 bp upstream of the gusA AUG, by Kpn I digestion of pLAMH10me and by the $3^{\prime} \rightarrow 5^{\prime}$ exonuclease activity of Klenow in the presence of dGTP thus yielding the translational fusion pLAMH10mk.

The hygromycin phosphotransferase gene under control of the $35 \mathrm{~S} \mathrm{CaMV}$ promoter and the nopaline synthase polyadenylation signal was present on pMOG24 (gift from Dr P.J.M. van de Elzen, MOGEN Int., Leiden). The reading frame of the $h p t$ gene was isolated as a $1058 \mathrm{bp}$ fragment from pJR255 [14]. This fragment runs from $14 \mathrm{bp}$ upstream of the AUG of the reading frame to $15 \mathrm{bp}$ after its TAG termination codon. At position -5 the $G$ was changed into $A$ to remove an AUG codon out phase with the reading frame. To the fragments CGGGATCCCG Bam HI linkers were ligated and the fragment was cloned into the Bam HI site of pROKI [2], which separates the CaMV $35 \mathrm{~S}$ promoter and nopaline synthase polyadenylation site, yielding pVU1011. By Bam $\mathrm{HI}$ digestion and Klenow fill-in reactions the Bam HI sites were removed thus yielding pMOG24.

A pIC plasmid containing the hpt gene cassette was constructed from pMOG24 so that upstream of the $35 \mathrm{~S}$ promoter a Bam HI site was present and downstream of the nos polyadenylation sequence a $B g l \mathrm{II}$ site.

From this pLAMHYG3 construct the selection gene was shuttled into the Bam HI site of the pLAMH* constructs as a $B a m$ HI- $B g l$ II fragment. Orientation of the hpt gene was checked by $E c o$ RV, Bam HI and $B g l$ II digestion. Constructs were named pLAMHH13m, HH27l, HH10mk and HHR $13 \mathrm{~m}$.

As a last step the Hind III fragments of these constructs, containing the artificial T-DNA, were cloned into the wide-host-range plasmid pMP92 cut with Hind III. The pMP92 was derived from pTJS75 [46] by insertion of a polylinker into the Hind III site.

Vector constructs were transferred from $E s c h e-$ richia coli to Agrobacterium tumefaciens or $A$. rhizogenes strains by triparental matings using pRK2013 as the helper plasmid [4, 18].

After transfer to the various Agrobacterium strains, the structure of the artificial T-DNA was checked by Southern analysis of DNA isolated from the ex-conjugants (data not shown).

\section{Protein analysis and western blot analysis}

SDS-Page was carried out according to Laemmli [26], using the LKB-Midget system (7.5\% acrylamide). Before loading samples were centrifuged $(14000 \mathrm{rpm})$ for $5 \mathrm{~min}$ and the supernatans were heat-denaturated after bringing the sample to $2 \%$ SDS, 5\% 2-mercaptoethanol, $10 \%$ glycerol, $0.001 \%$ bromophenol blue and $62.5 \mathrm{mM}$ Tris. Protein extracts containing $100 \mu \mathrm{g}$ protein were loaded. For the purified bacterial $\beta-D$ glucuronidase (Boehringer) $0.1 \mathrm{ng}$ per lane was used. Electrophoresis was for one hour at $25 \mathrm{~mA}$. Proteins were transferred to Immobilon (Millipore) filters by semi-dry blotting for $60 \mathrm{~min}$ at $0.8 \mathrm{~mA} / \mathrm{cm}^{2}$ with $25 \mathrm{mM}$ Tris, $192 \mathrm{mM}$ glycine and $20 \%$ methanol as transfer buffer. The GUS protein was detected with polyclonal antibodies (Sanbio) against GUS, 1/800 diluted in PBS, $0.5 \%$ Tween, $20 \%$ milk powder (incubation overnight at room temperature) and alkaline phosphatase-conjugated anti-rabbit IgG as secondary antibody.

\section{Plant transformation}

Transformation of Nicotiana tabacum cv. Petit Havanna $\mathrm{SR}_{1}$ was performed by leaf disc cocultivation. Three days after the cocultivation bacteria were killed by transfer to media containing $200 \mathrm{mg} / 1$ cefatoxime and $100 \mathrm{mg} / 1$ vancomycin. First selection for transformed cells was performed 10 days after cocultivation by transfer to 
the same medium containing in addition $50 \mathrm{mg} / \mathrm{l}$ hygromycin. 30 days after the cocultivation step hygromycin-resistant $\left(\operatorname{Hyg}^{\mathrm{R}}\right)$ calli were resuspended separately in MS medium [32] containing $0.1 \mathrm{mg} / 1 \mathrm{BAP}$ and $1 \mathrm{mg} / 1 \mathrm{NAA}$ and all three antibiotics, and were plated on solid medium. This step was performed to prevent chimaeric transgenic callus and plants in subsequent steps. About 5 weeks later parts of $\mathrm{Hyg}^{\mathrm{R}}$ calli were histochemically tested for GUS activity and remainders of the callus were transferred to MS medium containing $1 \mathrm{mg} / 1$ kinetin, $0.03 \mathrm{mg} / 1 \mathrm{NAA}$, cefotaxime and vancomycin for the formation of shoots. Shoots were transferred to MS medium. For each independent transformed callus, shoots were transferred to the greenhouse for selfing and reciprocal crosses with non-transgenic $S_{1}$ plants. Seeds were sterilized and sown onto solid MS-medium and MS medium containing $100 \mathrm{mg} / \mathrm{l}$ hygromycin. In preliminary experiments it was shown that wild-type $\mathrm{SR}_{1}$ seed displayed a delayed germination and a complete block of outgrowth on medium containing $50 \mathrm{mg} / 1$ hygromycin (data not shown). The number of $\mathrm{Hyg}^{\mathrm{R}}$ loci was calculated and corrected for germination frequency on medium without the selective agent.

\section{$D N A / R N A$ isolation and GUS assays}

Four weeks after sowing on $100 \mathrm{mg} / \mathrm{l}$ hygromycin, half of the resistant seedlings were transferred to MS medium containing $30 \mathrm{~g} / 1$ sucrose without hygromycin and maintained in vitro. The other half was transferred to soil in the greenhouse. 8.5 and 16 weeks after sowing 25-30 sister plants for each transformant were harvested from both the greenhouse and culture room. Individual plants can show variation in the expression of their genes. The variation was kept minimal in this study by analysis of pooled tissues from 25-30 plantlets for each time point. Leaves and stems were separately pooled from roots and frozen in liquid nitrogen, milled in a mortar. From the still frozen powder a sample was taken for determination of GUS activity and for western blotting. $200 \mu 1$ extraction buffer [23] was added to ca.
$50 \mathrm{mg}$ of powder and after thawing the sample was centrifuged at $10000 \times g$ for 5 minutes. Protein concentration was determined according to Bradford [5] using a commercial kit from Biorad. Samples were frozen again in liquid nitrogen and stored at $-80^{\circ} \mathrm{C}$. GUS activities were measured employing three different assays. One employed the compound $p$-nitrophenol- $\beta$ - $D$-glucuronide, and the activity was measured as described by Jefferson et al. [22]. The other two assays employed methylumbelliferyl- $\beta-D$-glucuronide as substrate. Activity was determined as described by Jefferson et al. [23] using different concentrations of extracted proteins. In previous experiments some samples appeared to contain an inhibitory compound. Inhibition could be overcome by using less extract in the assay. For all samples described in this study a linearity between GUS activity and the amount of extract used was found. A third alternative measurement was included. In this assay the reaction was terminated by adding TCA (final concentration $5 \%$ ) and a precipitation step to prevent quenching by proteins. The sample was made basic by addition of sodium hydrogen carbonate and fluorescence was measured. Optimal activities determined by the three methods did not deviate by more than $20 \%$ for all samples.

The rest of the (still frozen) powder was used for a combined RNA/DNA isolation according to Hensgens et al. [15] and Meyer et al. [29]. DNA and RNA concentrations were quantified by O.D. measurements.

\section{Induction of GUS activity by wounding}

From the progeny of plants $6,7,9,11,12,13$ and a control non-transgenic SR1 plant five plants were grown in the greenhouse. When the 35 plants reached a height of $65-70 \mathrm{~cm}$ and had $13-14$ leaves, the five uppermost leaves of all plants were harvested. For each progeny leaves were distributed over five pools. In this manner each pool contained one leaf from each individual plant and leaves with different sizes. All leaves were divided in two parts by removing the main vein. The parts 
were transferred onto humid filter discs in Petri dishes. One half of each leaf was wounded by puncturing numerous small holes employing a stainless steel brush. Pooled (un)wounded leaves were frozen $0,4,6.5$ and $20 \mathrm{~h}$ after wounding. Frozen leaves were ground and processed for GUS and transcript analysis as described above.

\section{Histochemical staining}

Histochemical staining for GUS activity was as described by Rueb and Hensgens [43].

\section{Results}

\section{Construction of chimaeric constructs}

Three chimaeric gusA genes differing in their $5^{\prime}$ upstream regions were constructed. The $521 \mathrm{bp}$
Cla I-Nla IV fragment (T-DNA 20.128-20.649 [1]) contained the promoter region of both mas genes $2^{\prime}$ and $1^{\prime}$. In this region the transcription of these genes starts in opposite direction. The indicated fragment was fused in three different ways to the gus $A$ reading frame. This yielded the constructs HH13m, HHR13m, HH271 and HH10mk (Figs. 1 and 2). Constructs HH13m and HHR $13 \mathrm{~m}$ are transcriptional fusions with the promoter of gene $2^{\prime}$. Within these constructs the AUG initiation codon of gene $2^{\prime}$, part of the used Cla I site, is 16 nucleotides separated from the AUG initiation codon of the gusA reading frame. In construct $\mathrm{HH} 271$ the nucleotides $\mathrm{AU}$ of the $A U G$ of gene $2^{\prime}$ were removed to prevent any interference of this out of frame codon with the AUG of the gusA reading frame (Fig. 2). In construct $\mathrm{HH} 10 \mathrm{mk}$ the Nla IV-Cla I fragment is fused to the gusA reading frame in inverted orientation. The promoter together with the first 38 nucleotides of the reading frame of gene $1^{\prime}$ as well as

A:
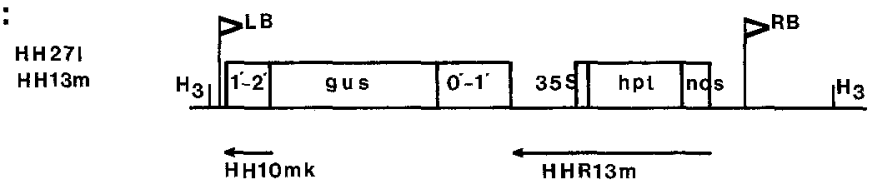

B:

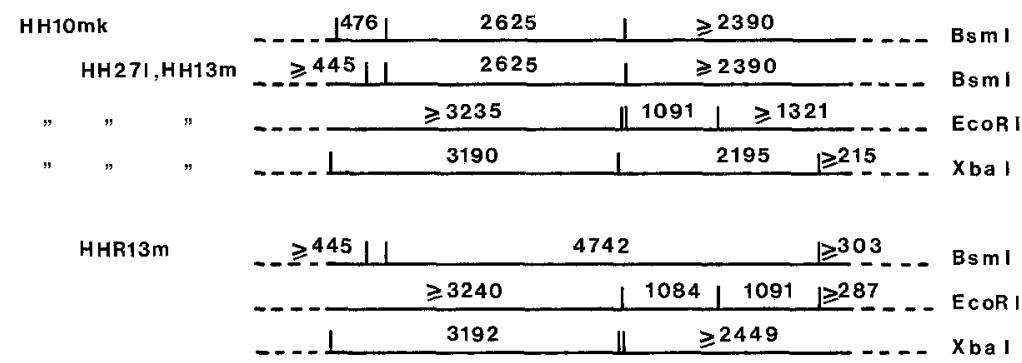

Fig. 1. Artificial T-DNA used for transformation of tobacco. Panel A: the Hind III fragment, containing the artificial T-DNA, which was shuttled into the wide host range plasmid is shown. All constructs contain the hygromycin phosphotransferase gene (hpt) under control of the $35 \mathrm{~S} \mathrm{CaMV}$ promoter and NOS termination sequence and the reporter gene coding for $\beta$ - $D$-glucuronidase (gus $)$ under control of the promoter of gene 2' (HH27l and $\mathrm{HH} 13 \mathrm{~m})$ or gene $1^{\prime}$ (HH10mk) and the termination sequence of gene $0^{\prime}$. Genes $0^{\prime}, 1^{\prime}$ and $2^{\prime}$ are from the $T_{\mathrm{R}}$-DNA of the octopine plasmid pTiAch5. Reading frames and regulatory sequences are indicated by boxes. Triangles ( $\mathrm{LB}$ and $\mathrm{RB}$ ) indicate border sequences involved in the transfer of T-DNA from Agrobacterium to plant cells [42]. Lines with arrowheads indicate sequences with reverse orientation in constructs as indicated. Panel B: restriction enzyme maps of the constructs used in this study. Dotted lines indicate fusion fragments which arise when the T-DNA integrates into the plants chromosome. Minimal sizes for these junction fragments are given in bp. The restriction maps of the artificial T-DNAs were deduced from the sequence assembled from the different cloning steps. 


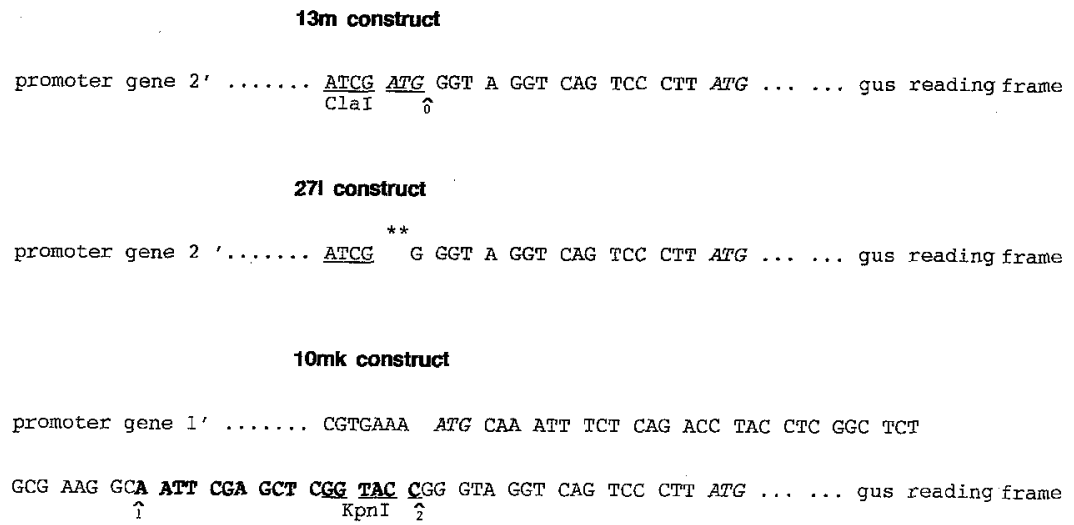

Fig. 2. Sequences flanking the AUG initiation codon of the $g u s A$ reading frame as present in the constructs. The asterisks indicate the deleted nucleotides AT. $\uparrow^{0}$ indicates the fusion between Cla I site and remainder of $S m a$ I site (GGG). $\uparrow^{1}$ indicates the fusion between half Nla IV site (GCC) with filled-in Eco RI site (AATTC). $\uparrow^{2}$ remainder of Sma I site (CCGGG) of pB101.1, one $\mathrm{C}$ was deleted to make a translational fusion. The shadowed bases are derived from the polylinker region of pIC-20H. (See for further details Materials and methods.)

in total 34 nucleotides from the pIC-20H polylinker and the upstream region of $\mathrm{pB} 101.1$ [22] are fused to the gusA reading frame. Theoretically, this construct might lead to two proteins, one encoded by the gusA reading frame alone and one starting at the AUG of gene 1' being 24 amino acids longer.

The hygromycin phosphotransferase gene (hpt) was used as selection gene. It functions under control of the $35 \mathrm{~S} \mathrm{CaMV}$ promoter and the nopaline synthase polyadenylation signal sequence $[48,37]$ (Fig. 1). This gene was also used as a marker gene for internal reference in northern blot analysis. The $35 \mathrm{~S} \mathrm{CaMV}$ promoter contains enhancer sequences [25, 33]. The effect of these sequences on GUS expression was studied by inversion of the $h p t$ gene cassette (the $2175 \mathrm{bp}$ Bam HI-Bgl II fragment) in the construct HHR13m (Fig. 1) By this inversion the distance between the putative enhancer sequences (490 bp upstream of the AUG of the hpt gene) and the AUG of the gusA reading frame is increased from 3012 to 4013 bp relative to the situation in construct $\mathrm{HH} 13 \mathrm{~m}$.

\section{Plant transformation}

Transgenic calli were obtained by cocultivation of leaf discs with different Agrobacterium strains (Table 1). In these experiments we observed that the gusA fusions gave considerable GUS activity in all Agrobacterium strains used and that the presence of the $35 \mathrm{~S} \mathrm{CaMV} \mathrm{hpt} \mathrm{gene} \mathrm{rendered}$ agrobacteria resistant to hygromycin at concentrations of $100 \mu \mathrm{g} / \mathrm{ml}$ while strains without the gene appeared to be sensitive to concentrations of $20 \mu \mathrm{g} / \mathrm{ml}$. To exclude any possible interference of contaminating bacteria in expression studies as well as variable results due to chimaeric plants we

Table 1. Characteristics of Agrobacterium strains used in this study.

\begin{tabular}{|c|c|c|}
\hline LBA 1197 & $\mathrm{Km}^{\mathrm{R}}, \Delta \mathrm{T}-\mathrm{DNA}$ & Deblacre et al. [8] \\
\hline LBA 1198 & pTiB6, tra $a^{\mathrm{c}}, \mathrm{pBRTc}^{\mathrm{s}}, \mathrm{Ap}^{\mathrm{R}}, \mathrm{Rif}^{\mathrm{R}}, \mathrm{Km}^{\mathrm{S}}$ & Deblaere et al. [8] \\
\hline LBA 4404 & pTiAch5, $\triangle \mathrm{T}-\mathrm{DNA}$ & Hoekema et al. [16] \\
\hline LBA 1060 & pRi1855 (C58, chromosomal) & Offringa et al. [36] \\
\hline LBA 9402 & pRi1855 (1855 chromosomal) & Hoekema et al. [17] \\
\hline
\end{tabular}


studied gene expression in $\mathrm{F}_{1}$ progenies. Regenerants were transferred to the greenhouse and allowed to flower. Plants were back-crossed with non-transgenic $N$. tabacum cv. Petit Havanna $\mathrm{SR}_{1}$ plants. The progeny of these crosses were allowed to germinate on MS medium containing $100 \mu \mathrm{g} / \mathrm{ml}$ hygromycin. Concentrations of $50 \mu \mathrm{g} /$ $\mathrm{ml}$ completely blocked shoot development from untransformed seed. Transgenic seeds containing an active $h p t$ locus developed into normal plantlets even at concentrations of $100 \mu \mathrm{g} / \mathrm{ml}$ hygromycin. The number of hygromycin-resistant seedlings was scored three weeks after seeding. The number of active loci was determined with the $\mathrm{X}^{2}$ method (Table 2) and varied from 1 to 5 in the various transformants.

Three weeks after sowing, resistant seedlings were transferred to MS medium without hygromycin or were transferred to the greenhouse in soil. For each offspring plants were grown in vitro and in the greenhouse. At ages of 8.5 weeks and 16 weeks respectively tissues from 21 or more individual plants were pooled and analyzed for the number and integrity of the integrated T-DNA copies (Southern analysis). The mRNA levels and GUS activities were studied employing the same pooled tissues.

\section{Copy number of transferred genes}

The number and the integrity of T-DNA copies in pooled $\mathrm{Hyg}^{\mathrm{R}}$ plants was determined by Southern blot analysis. Figure 3 shows the Southern blots using Eco RI, $X b a \mathrm{I}$ and $B s m$ I. The number of T-DNA copies was estimated from the intensities of bands corresponding to the internal Eco RI (1091 or $1084 \mathrm{bp}$ ), Bsm I (2625 or $4742 \mathrm{bp}$ ) and $X b a$ I (3190 and/or $2195 \mathrm{bp}$ ) fragments and from the number of bands correspond-

Table 2. Summary of genetic analysis of progenies of the transformed regenerants, Southern analysis and histochemical assays on hygromycin-resistant seedlings.

\begin{tabular}{|c|c|c|c|c|c|c|}
\hline Plant & Callus & Strain/construct & $\begin{array}{l}\text { Number of loci } \\
\left(\mathrm{X}^{2}\right)\end{array}$ & $\begin{array}{l}\text { Number of integrated } \\
\text { copies }\end{array}$ & $\begin{array}{l}\text { Number of left } \\
X b a \text { I sites } \\
\text { not cut }\end{array}$ & $\%$ Gus $^{-} / \mathrm{HygR}$ \\
\hline 1 & \multicolumn{6}{|c|}{ untransformed } \\
\hline 2 & $9 \mathrm{cWOA}$ & LBA1197/HH13m & $2(70 \%)$ & 2 & - & $\mathrm{nt}$ \\
\hline 3 & $7 \mathrm{aWOK}$ & LBA1197/HH13m & $3(45 \%)$ & $3^{\mathrm{a}}$ & 1 & $\mathrm{nt}$ \\
\hline 4 & $1 \mathrm{Cl}(\mathrm{I})$ & LBA4404/HH13m & $4-5(25 \%)$ & $6-7^{b}$ & - & $\mathrm{nt}$ \\
\hline 5 & $12 \mathrm{WO}$ & LBA1198/HH13m & $2(55 \%)$ & $2^{\mathrm{c}}$ & 2 & $\mathrm{nt}$ \\
\hline 6 & $5 \mathrm{~B} 2(\mathrm{I})$ & LBA4404/HHR13m & $1(40 \%)$ & $1^{d}$ & 1 & 100 \\
\hline 7 & $1 \mathrm{~A} 2(\mathrm{II})$ & LBA4404/HH10mk & $1(70 \%)$ & 1 & - & 0 \\
\hline 8 & $7 \mathrm{~A} 3$ & LBA4404/HH10mk & $1(90 \%)$ & $1^{\mathrm{a}, \mathrm{e}}$ & - & $\mathrm{nt}$ \\
\hline 9 & $10 \mathrm{~A} 3$ & LBA4404/HH $10 \mathrm{mk}$ & $2(60 \%)$ & 2 & 2 & 50 \\
\hline 10 & $6 \mathrm{E} 4(\mathrm{IV})$ & LBA1197/HH271 & $2(60 \%)$ & 2 & 2 & 0 \\
\hline 11 & $5 \mathrm{E} 5$ & LBA1197/HH271 & $2(15 \%)$ & $3^{f}$ & 1 & 0 \\
\hline 12 & 4D3(II) & LBA4404/HН271 & $5(55 \%)$ & $3^{\mathrm{g}}$ & 3 & $\mathrm{nt}$ \\
\hline 13 & 8D3(II) & LBA $4404 / \mathrm{HH} 271$ & $3(15 \%)$ & 3 & 3 & 30 \\
\hline
\end{tabular}

a Only $3.75 \mu \mathrm{g}$ DNA was used in the Southern analysis.

b 3 copies form a tandem repeat with a $1000 \mathrm{bp}$ spacer in between. This explains the relative strong hybridization with the $B s m \mathrm{I}$ $3835 \mathrm{bp}$ and the $5560 \mathrm{bp} E c o R I$ fragments.

${ }^{c}$ Both copies are probably deleted for at most $445 \mathrm{bp}$ from the left-border sequence.

d Tandem repeat and partly scrambled.

e $476 \mathrm{bp} \mathrm{Bsm}$ I fragment is lacking, probably no intact $1^{\prime}$-gusA fusion is present. Intensity of bands and patterns suggest that amplification and scrambling at one locus has taken place.

f 2 copies form a tandem repeat and lack the $X b a$ I site close to the left border.

g 2 copies are probably the result of amplification.

$\mathrm{nt}=$ not tested. 

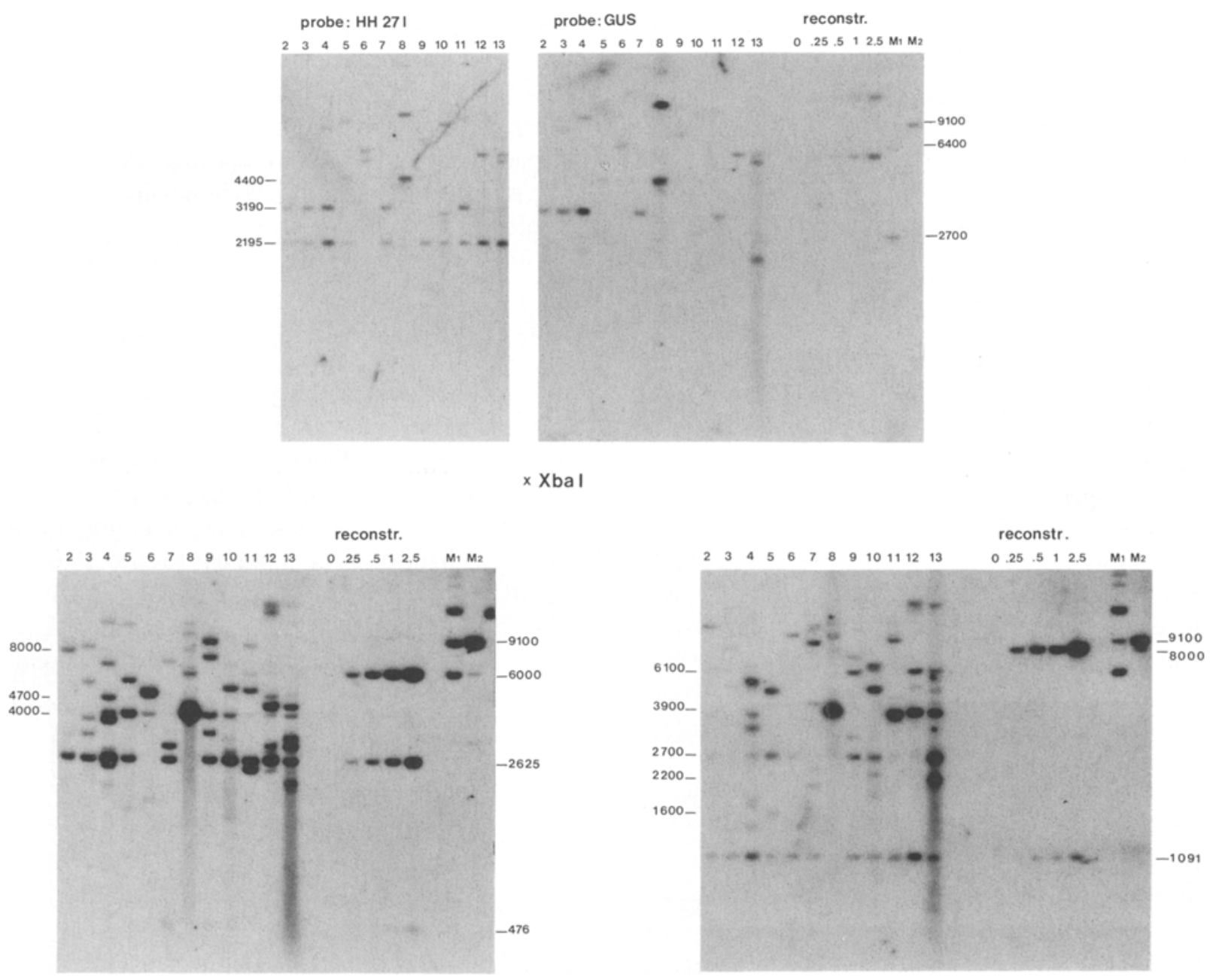

Fig. 3. Southern blot analysis of transgenic $\mathrm{F}_{1}$ plantlets derived from primary transformants. For each pool $5 \mu \mathrm{g}$ DNA was digested with $X b a$ I, $E c o$ RI or $B s m$ I, separated and blotted onto GeneScreen Plus and hybridized. As probe the Hind III fragment from HH27l was used and for some $X b a$ I digestions also gusA cloned into pIC plasmid was used. Reconstr.: $5 \mu \mathrm{g}$ control untransformed tobacco was digested with the appropriate enzyme and mixed with a cloned Hind III fragment in pIC digested with the appropriate enzyme. $0,0.25,0.5,1$ and 2.5 copies of the HH271 pIC plasmid were mixed per diploid tobacco genome. M1, and $\mathrm{M} 2$ are molecular weight markers. Numbers above the lanes correspond to the transformants listed in Table 2.

ing to junction fragments joining the plant DNA with the T-DNA. The number of integrated copies varied from 1 to 7 (Table 2). Four out of twelve progenies contained tandem repeated copies or scrambled copies (Table 2). All progeny, except of plant 8, contained a 1091 bp Eco RI fragment representing an intact $35 \mathrm{~S}$ CaMV $h p t$ fusion (Fig. 3). The situation is more complex for the fragment consisting of the $2^{\prime}-1^{\prime}$ promoter fused to the gusA gene. A 3190 bp (3192) Xba I fragment is expected for the intact T-DNA (Fig. 1). This fragment is not observed, however, in the progeny of plants $5,6,8,9,10,12$ and 13 . Apparently the $X b a$ I site located $13 \mathrm{bp}$ right from the left border is not detected in these plants (Fig. 3, Table 2). This can be due to methylation or, more likely, to a deletion of a sequence at the left border. Gheysen et al. [13] showed that de- 
letions up to $50 \mathrm{bp}$ at the left border of T-DNA are frequently present. In all plants, except for the progeny of plant 6 and 8, a 2625 or 4742 bp Bsm I fragment spanning the gus $A$ reading frame is observed (Figs. 1 and 3). Thus the Bsm I site $56 \mathrm{bp}$ downstream of the AUG of the gus $A$ gene is conserved. An intact promoter region of $\mathrm{HH} 10 \mathrm{mk}$ in transgenics is expected to yield a $476 \mathrm{bp} \mathrm{Bsm} \mathrm{I}$ fragment (Fig. 1). Two of the three analysed HH $10 \mathrm{mk}$ progenies displayed a band corresponding to this fragment indeed (Fig. 3, lanes 7-9). This means that the $B s m$ I site $176 \mathrm{bp}$ downstream of the left border is conserved in plants 7 and 9 . We therefore conclude that in most progenies the promoter region upstream of the gusA reading frame is intact. The expression data support this view. Only the progeny of plants 6 and 8 probably contained deletions interfering with the expression of the gus $A$ reading frame (see also below).

\section{Expression of transferred genes}

Leaves and roots were harvested from 20 or more in vitro grown plantlets ( 8.5 weeks old). For each progeny leaves and roots were pooled separately. The steady-state concentration of GUS and HPT transcripts in leaves and roots of the different offsprins was studied by northern blot analysis. In each lane the same amount of total RNA $(5 \mu \mathrm{g})$ was loaded. The integrity of the RNA was checked by ethidium bromide staining before transfer (not shown). In most samples, except those of progenies of plants 6 and 8, two bands are observed with mobilities which correspond to the expected sizes of the GUS transcript (2340 nucleotides) and HPT transcript (hyg; 1235 nucleotides). The nature of these two bands was further confirmed with gusA- and hpt-specific probes (see also below). As can be expected from the $\mathrm{Hyg}^{\mathrm{R}}$ phenotype, in all plants a HPT transcript (hyg) is observed both in roots and leaves. In roots its relative concentration was always lower than in leaves.

The transgenic offspring of the HHR $13 \mathrm{~m}$ plant 6 (Fig. 4, lane 6) contained a significantly smaller
GUS transcript, only detectable in the green parts of the plantlets. The offspring of the HH10mk plant 8 (lane 8) completely lacked GUS RNA. The amount of HPT and GUS transcripts is clearly not directly correlated with the number of integrated genes. Although the offspring of plant 4, containing 6-7 copies (Table 2), displayed the highest amount of HPT and GUS transcripts indeed, other progenies, such as those of plants 6 , 7 and 8 with only one hpt gene, did not have less HPT transcript than progenies containing 2-3 copies.

GUS activity, measured in extracts made from the same samples as used for RNA analysis, varied greatly (Fig. 4, right panel). For the same plants it was found that GUS activity in root extracts from $\mathrm{HH} 10 \mathrm{mk}$ and $\mathrm{HH} 271$ plants (7-13) (1640 to $3570 \mathrm{nmol} \mathrm{mg}{ }^{-1} \mathrm{~h}^{-1}$ ) are 3-11 times higher than in leaf extracts ( 200 to $758 \mathrm{nmol} \mathrm{mg}{ }^{-1}$ $\left.\mathrm{h}^{-1}\right)$. The highest enzyme activity $(3570 \mathrm{nmol}$ $\mathrm{mg}^{-1} \mathrm{~h}^{-1}$ ) was observed in roots of the progeny of plant 9 (HH10mk). The large difference in GUS activity between root and leaf tissue does not correspond with different levels of GUS transcript (Fig. 4, left panel).

Progeny of plants 2-5 transformed with $\mathrm{HH} 13 \mathrm{~m}$, containing the out-of-phase AUG codon upstream of the gus $A$ reading frame (constructs $\mathrm{HH} 13 \mathrm{~m}$ and HHR $13 \mathrm{~m}$ ) contained a low but distinct GUS activity in leaves (55 to

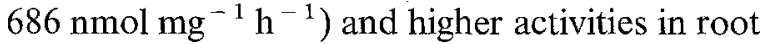
tissue (148 to $1464 \mathrm{nmol} \mathrm{mg}^{-1} \mathrm{~h}^{-1}$ ). These values are about 6 times lower than those found for the plants transformed with $\mathrm{HH} 271$ (plants 1013).

\section{Expression in plants grown in vitro and in the green-} house

The influence of growth conditions and age on the expression of the different gusA constructs was studied. Plants were grown for 8.5 or 16 weeks in vitro as well as in the greenhouse for the same periods. Leaf and root tissues were harvested separately from 20 or more pooled $\mathrm{Hyg}^{\mathrm{R}}$ plants of transformants 9, 4, 13 and 10 for all four ex- 


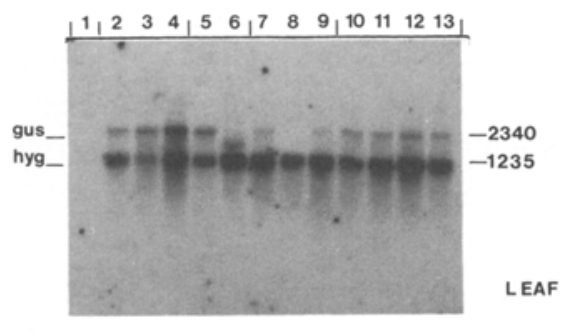

GUS activity

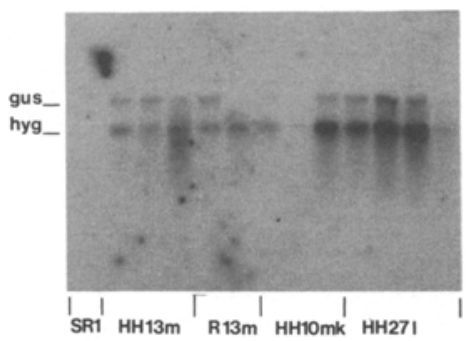

ROOT

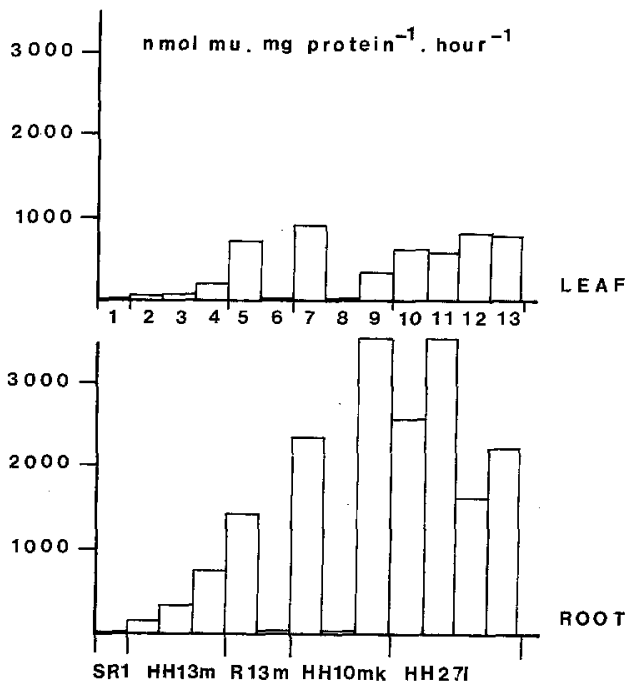

Fig. 4. Transcript analysis and GUS activities of transgenic $F_{1}$ progenies. Panel A: $5 \mu \mathrm{g}$ total RNA isolated from pooled leaf and root material was separated on a $1.4 \%$ non-denaturating agarose gel, blotted onto GeneScreen and hybridized with nick-translated HH271 (pIC) plasmid DNA. Numbers above the lanes correspond to numbers of the transformants given in Table 2. gus and hyg indicate the transcripts derived from the $\beta$ - $D$-glucuronidase and hygromycin phosphotransferase gene. Their sizes are given in nucleotides. Panel B: GUS activities measured in extracts made from the same pooled and milled fractions from which RNA was isolated.

perimental groups. The different environmental conditions had a remarkable influence on GUS activity (Fig. 5, panel B). In vitro grown plants showed in root extracts a GUS activity that is 4 to 40 times higher than in leaf extracts. Greenhouse-grown plants, however, showed a similar but less pronounced difference between roots and leaves. The differences observed in GUS activity do not correlate with GUS mRNA levels (Fig. 5, panel A). Root samples containing high GUS activities, like those of plants 9 and 10 grown in vit$r o$, have the lowest levels of GUS mRNA.

It can be stated that in general plants grown in the greenhouse contain more GUS transcript despite a lower GUS activity than found in sister plants grown in vitro. For leaf material also no correlation exists between GUS activity and level of mRNA. The in vitro grown plantlets display the highest GUS activities while their GUS mRNA level is equal to or lower than in greenhouse- grown sister plantlets. In the HH13m plant 4 (Fig. 5) the GUS transcript is very abundant under all conditions compared with the other plants.

One explanation for the clear discrepancy between GUS activity and steady-state levels of mRNA could be an inactivation of the GUS protein by glycosylation. To study this possibility, the protein extracts, also used for activity determination, were analysed by western blots using polyclonal antibodies raised against the GUS protein. It can be seen from Fig. 5, panel C, that the relative intensities of the GUS bands correspond well to the measured GUS activities. In addition, most bands have the same relative mobility as pure E. coli GUS protein (lanes g in Fig. 5, panel C). Extracts from greenhouse-grown plants often yielded some background and a GUS band with a slightly different migration behaviour (eg. roots from plants 9 and 10 ). Mixing $E$. coli GUS pro- 
Expression of the GUS and Hyg gene

in transgenic SR-1
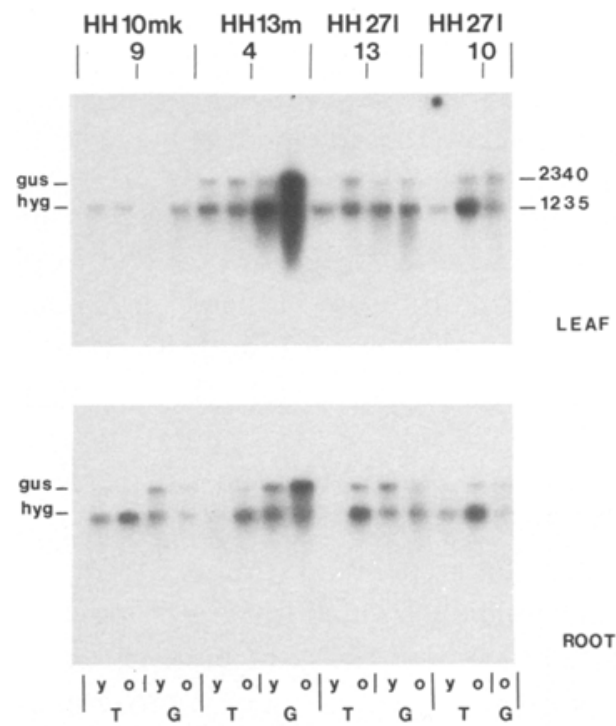

$\mathbf{T}=$ Cultureroom

$\mathrm{G}=$ Greenhouse $y=8.5$ weeks

$0=16$ weets A

\section{GUS activity}

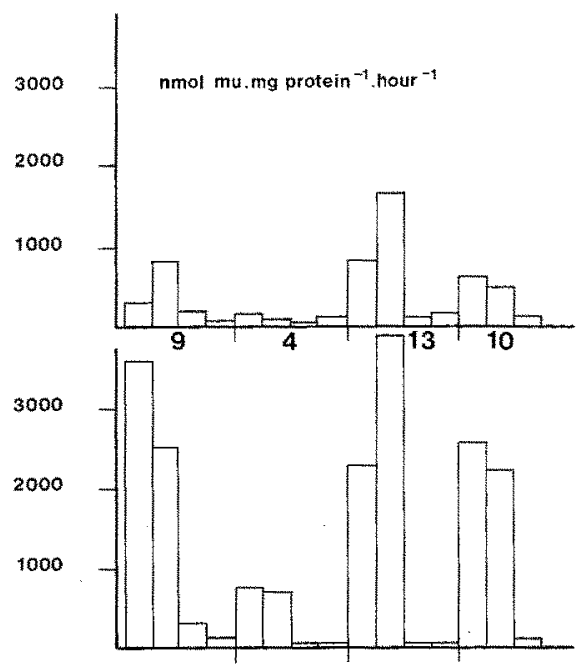

B

\section{9:HH10mk}

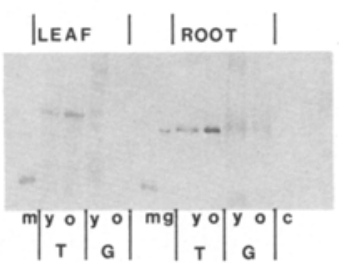

13: $\mathrm{HH} 27$

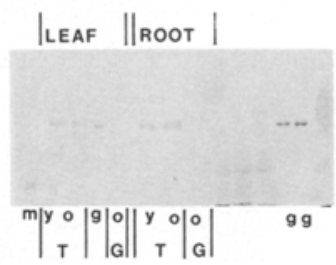

4: HH13m

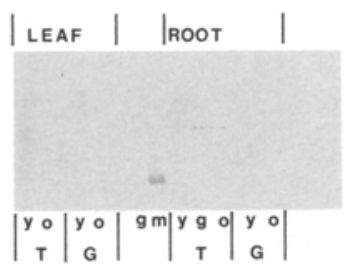

10: HH 27 I



Fig. 5. Transcript analysis, GUS activities and protein analysis of transgenic $\mathrm{F}_{1}$ progenies of plants $9,4,13$ and 10 grown in vitro or in the greenhouse for 8.5 and 16 weeks. Panel A: $5 \mu \mathrm{g}$ total RNA isolated from pooled leaf and root material was separated on a $1.4 \%$ non-denaturating agarose gel, blotted onto GeneScreen and hybridized. (See for further details Fig. 4). Panel B: GUS activities measured in extracts made from the same pooled and milled tissues. Activities in extracts are displayed in the same order as in panel A. Panel C: western blot analysis of protein extracts from panel B. $m=$ molecular weight marker; $G=$ greenhouse-grown plants; $\mathrm{T}=$ in vitro plants grown in jars under artificial light conditions; $\mathrm{y}$ and $\mathrm{o}$ indicate plants grown for 8.5 and 16 weeks; $\mathrm{g}=E$. coli $\beta$ - $D$-glucuronidase; $\mathrm{c}=$ extracts made from control untransformed SR-1 plants grown in vitro. (See for further details Materials and methods.) 


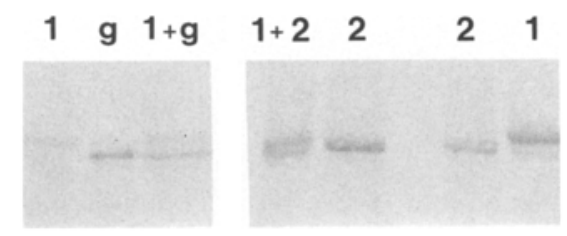

Fig. 6. Western blot analysis of GUS protein. Lanes 1 contain extracts from pooled leaves from $F_{1}$ progeny of plant 9 (Table 2) grown in vitro for 16 weeks. Lanes 2 contain extract from pooled leaves from $F_{1}$ progeny of plant 10 (Table 2) grown in vitro for 16 weeks. From both extracts $100 \mu \mathrm{g}$ protein was loaded, when they were combined only $65 \mu \mathrm{g}$ of each was loaded. Lane g contains $0.1 \mathrm{ng}$ of a commercial $E$. coll $\beta$ - $D$-glucuronidase. (See for further details Materials and methods.)

tein with these extracts showed that they have the same mobility as the $E$. coli protein. Therefore, we assume that glycosylation does not play a role.

Leaf extracts from the offspring of plant 9 (HH10mk) grown in vitro showed besides a weak band with the same mobility as the $E$. coli protein a strong band with a higher molecular weight (Fig. 5, panel C). The amount of protein loaded in the E. coli GUS lanes was $10^{6}$ times lower as in lanes containing plant extracts. This probably caused small differences in mobility between the samples. To verify the presence of two GUS bands in the leaf tissue of the progeny derived from the HH10mk transgenic plant 9 samples were mixed and analyzed (Fig. 6). Two bands were detected for the leaf extracts from this transgenic offspring (Fig. 6, lanes 1). The intensity of the high-molecular-weight band was about 10 times stronger than found for the low-molecularweight band. This low-molecular-weight band had the same mobility as the native $E$. coli GUS
(Fig. 6, lanes $\mathrm{g}$ and $1+\mathrm{g}$ ) and the GUS made in leaf tissue of plantlets from plant 10 transformed with HH27l (Fig. 5, panel C; Fig. 6, lanes 2 and $2+1)$.

\section{Expression patterns in tumours}

The expression of the gusA fusions was also studied in the different cell types present in plant tumours. Tumours were induced on Kalanchoe tubiflora, Nicotiana rustica and Nicotiana glauca. Agrobacterium rhizogenes LBA 1060 and LBA9402 (Table 1) containing the construct HH13m, HH27l and HH10mk in a binary set-up were used. For each strain and construct, sections of 15 independent tumours were made and histochemically stained for GUS activity (Fig.7).

Strains without the gusA construct never gave staining (Fig. 7, panels A). Microscopic examination showed that some (dead) plant cells of the tumours contained bacteria. These cells however did not stain blue upon histochemical staining for GUS activity, not even when tumours were induced with strains carrying the gus $A$ constructs.

Tumours with the HH13m construct on $K$. tubiflora gave staining mainly in all roots developing from the tumours and in some densely packed cells within tumours, which most likely are root primordia (Fig. 7, panels b). The patterns observed in tumours induced by strains carrying the $\mathrm{HH} 271$ or the HH10mk construct (Fig. 7, panels $c$ and d) are different. In these tumours the majority of cells and roots is stained with an intensity similar to that of the HH13m tumours. Tumours formed on the other plant species mentioned gave similar results. The $\mathrm{HH} 13 \mathrm{~m}$ construct

Fig. 7. Histochemical staining for GUS activity in hand-made transections of tumours induced on Kalanchoe tubiflora by Agrobacterium rhizogenes LBA 1060 containing the construct $\mathrm{HH} 13 \mathrm{~m}, \mathrm{HH} 27 \mathrm{l}$ and HH10mk or the empty binary plasmid pMP92. Staining was performed for $2 \mathrm{~h}$ at $37^{\circ} \mathrm{C}$ as described [23, 43]. For each construct 14-16 transections of independent induced tumours are shown. For each construct one transection is shown enlarged in the photographs with black background. At the bottom left the morphology of the root-forming tumours is shown. Panel e shows some details of the staining in a root of a tumour induced with construct $\mathrm{HH} 271$.

Fig. 8. Transcript analysis, GUS activities and histochemical staining for GUS activity in different parts of the HH27l plant 13 grown in vitro for 8 weeks. The position of the leaves, stem fragments and roots used for RNA and GUS analysis are indicated in the schematic drawing. Lanes $1-4$ and $\mathrm{R}$ correspond to the numbers in this drawing. Part of the harvested tissue was his- 

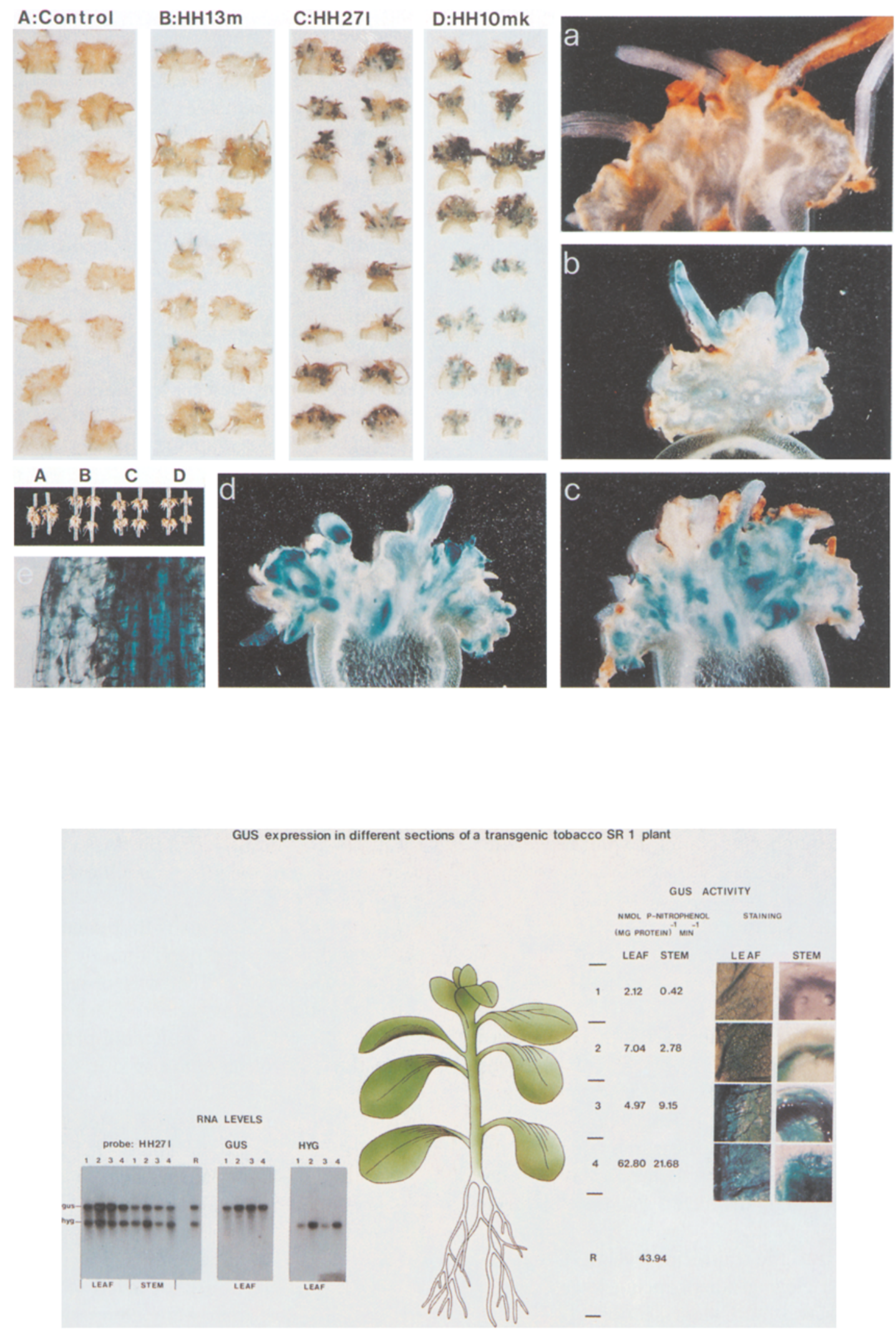

tochemically stained for GUS activity. The remainder was used for RNA analysis and GUS assays as described in Materials and methods. Transcript analysis was performed as described in Figs. 4 and 5. Besides the HH27l plasmid (panel HH271) also pIC plasmids carrying the guSA reading frame (panel GUS) or the hpt gene (panel HYG) were used as probes in this analysis. 
Table 3. Comparison of sequences flanking the initiation codons present in the constructs used. The upper line is a modified consensus sequence for dicot plants (compilation of 233 sequences) as described by Cavener and Ray [6]. The two nucleotides which occurred most frequently were taken. Italics indicate similarity with the consensus nucleotide with highest frequency. Underlined nucleotides are similar with the second most frequent nucleotide in the consensus sequence

\begin{tabular}{llllllllllllll}
\hline-10 & -9 & -8 & -7 & -6 & -5 & -4 & -3 & -2 & -1 & & +4 & +5 & \\
$\mathrm{a} / \mathrm{u}$ & $\mathrm{a} / \mathrm{u}$ & $\mathrm{a} / \mathrm{u}$ & $\mathrm{a} / \mathrm{u}$ & $\mathrm{a} / \mathrm{u}$ & $\mathrm{a} / \mathrm{c}$ & $\mathrm{a} / \mathrm{c}$ & $\mathrm{A}$ & $\mathrm{a} / \mathrm{c}$ & $\mathrm{A} / \mathrm{C}$ & $\mathrm{AUG}$ & $\mathrm{G}$ & $\mathrm{C}$ & (dicot plants) \\
$\mathrm{U}$ & $\mathrm{C}$ & $A$ & $\mathrm{G}$ & $\underline{\mathrm{U}}$ & $\underline{\mathrm{C}}$ & $\underline{\mathrm{C}}$ & $\mathrm{C}$ & $\mathrm{U}$ & $\mathrm{U}$ & $\mathrm{AUG}$ & $\mathrm{U}$ & $\mathrm{A}$ & (gusA) \\
$A$ & $\mathrm{C}$ & $A$ & $\mathrm{C}$ & $\mathrm{G}$ & $\mathrm{U}$ & $\mathrm{G}$ & $A$ & $A$ & $A$ & AUG & $\mathrm{C}$ & $\mathrm{A}$ & (gene $\left.1^{\prime} ; \mathrm{HH} 10 \mathrm{mk}\right)$ \\
$\mathrm{C}$ & $A$ & $\mathrm{C}$ & $\mathrm{C}$ & $A$ & $A$ & $A$ & $\mathrm{U}$ & $\underline{\mathrm{C}}$ & $\mathrm{G}$ & AUG & $G$ & $\mathrm{G}$ & (gene $\left.2^{\prime} ; \mathrm{HH} 13 \mathrm{~m}\right)$ \\
\hline
\end{tabular}

gave staining within root primordia only, while $\mathrm{HH} 271$ and $\mathrm{HH} 10 \mathrm{mk}$ gave staining in practically all tumour cell types.

Since tumours arise by multiple transformation events, these results show clearly that the observed root cell-specific expression of the $\mathrm{HH} 13 \mathrm{~m}$ construct is a reproducible not plant speciesspecific phenomenon.

\section{Accumulation of $\beta$-D-glucuronidase}

To circumvent plant-dependent variations in the experiments described above material was pooled from a large number of plants. Expression of the gusA and $h p t$ gene was also studied, however in leaves, stems and roots of individual plants. A representative example of the $\mathrm{HH} 271$ plant 13 is shown in Fig. 8. Sections from the same tissues as used for RNA analysis were histochemically stained for GUS activity.

The levels of GUS and HPT mRNAs were within the same order of magnitude for all leaves and were lower in roots and stem fragments. Young top leaves (Fig. 8, lanes 1) displayed a degree of hybridization in the same range as the older bottom leaves (lanes 4), while leaves in the mid (lanes 2 and 3) displayed a stronger hybridization.

In contrast to the transcript levels GUS activity showed a clear gradient, being lowest in the young top leaves and stem sections (2.12 and $0.42 \mathrm{nmol} \mathrm{min}{ }^{-1} \mathrm{mg}^{-1}$ ) and highest in the older parts (62.80 and $21.68 \mathrm{nmol} \mathrm{min}{ }^{-1} \mathrm{mg}^{-1}$ ). The observed differences in GUS activities were also expressed in different intensities of blue staining of the tissues. Comparable data from several of such experiments led us to conclude that GUS activity increases with ageing of the tissues while its mRNA level remains relatively constant.

\section{Discussion}

Four major conclusions can be drawn from the results shown: (1) GUS activities do not correlate directly with the level of its mRNA; (2) in vitro grown plants have much more GUS activity than sister plants grown in the greenhouse; (3) considerably higher GUS activity is found in roots than in leaves while leaves have in most cases the highest mRNA level; (4) different AUG codons are used by the translation machinery to initiate translation.

One of the conclusions is that measured GUS activities do not correspond directly to observed GUS mRNA levels. This was observed by enzyme and mRNA assays with extracts from tissues of different age of individual plants. We assume that this observation is due to the stable character and accumulation of the GUS protein during ageing together with a difference in turnover between the protein and its mRNA.

Another observation was that in vitro grown plants contain much more GUS activity than sister plants grown for the same period in the greenhouse. The in vitro grown plants, however, did not display higher GUS mRNA levels (Fig. 5). Also when GUS activities were compared between root and leaf material of in vitro grown plants, much more GUS activity was found in roots while in most cases more GUS mRNA was observed in the green tissue (Figs. 4 and 5). Comai et al. [7] described similar results, i.e. higher expression in 
roots and older parts of transgenic plants transformed with similar constructs. They speculated that the leader sequence of the mannopine synthase mRNA contained sequences by which transcription was enhanced within these tissues. The lower steady-state mRNA concentrations observed in roots in the present study suggest another explanation.

Our observations lead to the conclusion that translation of the GUS mRNA and the stability of the GUS protein play crucial roles in determining the ultimate level of GUS activity in the transformed tissues.

The data obtained show that the initiation of translation probably is the limiting step in determining the ultimate phenotype of the chimaeric gene. For our constructs initiation of translation was found to be different in roots and leaves.

Two GUS proteins with different mobilities were observed in the leaf material of the HH10mk transformants. The largest protein was approximately ten times more abundant than the smaller one which had the same mobility as the $E$. coli enzyme. Western blot analysis (Fig. 5 and data not shown) did not give any indication for specific breakdown or glycosylation of the GUS protein in any of the tissues studied. We therefore assume that in leaf the GUS mRNA is translated from both AUG initiation codons, with preference for the $5^{\prime}$-proximal codon. In roots only the smaller protein can be observed (Figs. 5 and 6); consequently, only the second more distal $\mathrm{AUG}$ is probably used.

The $20 \mathrm{bp}$ upstream of the AUG of the gusA reading frame is the same for all three constructs studied. The higher expression levels found in roots of all plants is probably the result of a more efficient initiation of translation on this codon in roots.

With some exceptions, translation on eukaryotic mRNAs starts at the most 5' -proximal AUG codon. Plant viruses display some exceptions to this. Some of them use leaky stop codons to express two in frame protein coding cistrons [31, $40,41,55]$. Other viruses probably also utilize ribosomal frame-shifting to couple translation of protein-coding regions which overlap in different reading frames $[30,50,54,55]$ as has been found also for animal retroviruses $[19,20]$. In most of these cases translation has been studied using cell-free systems. Our analysis is the first in vivo study showing that the translational machinery can select between two AUG codons present on the same mRNA to start translation. Furthermore it is the first time that it can be shown that the initiation can be controlled by external factors as for example stress.

Comparison of the sequences flanking the initiation codons used in this study with the consensus sequence for dicotylodonous plants as described by Cavener and Ray [6] does not reveal any clear homology of any of the sequences with the consensus sequence of dicot plants (Table 3 ). The flanking regions of the initiation codons of the genes $1^{\prime}$ and $2^{\prime}$ line up with 5 nucleotides in various positions while the sequence flanking the gusA AUG lines up with one A residue and shows similarity with $2^{\prime} \mathrm{C}^{\prime} \mathrm{s}$ and $2 \mathrm{~T}^{\prime}$ s when the second frequent nucleotides of flanking regions are included in the analysis. The sequence AAA present at position -321 upstream of the AUG of gene $1^{\prime}$ is the most frequent -321 triplet in non vertebrate species. The sequence upstream of the gusA AUG, exclusively used in roots, has the lowest similarity with the consensus sequence.

In roots of HH10mk transformants grown invitro, initiation of translation occurs exclusively at the initiation codon of the gus $A$ reading frame. However roots of $\mathrm{HH} 13 \mathrm{mk}$ transformants, with the extra AUG out of phase with the gusA AUG, synthesize less GUS protein than the roots of HH27l transformants lacking the extra AUG. The extra AUG out of phase clearly interferes with a correct initiation of translation, while the extra AUG in phase is not used at all in roots of HH10mk transformants. The translational machinery might have a higher affinity for the gene $2^{\prime}$ AUG (in HH13m, out of phase) than for the AUG of gene 1' (in HH10mk). This difference in affinity might result in a different competition for initiation. Whether the distance between the AUGs, 16 bases for $H H 13 \mathrm{~m}$ and 69 for $H H 10 \mathrm{mk}$, has any influence on this is not known.

The root-specific staining observed for tumours 
with the HH13m construct on the different studied species (Kalanchoe tubiflora, Nicotiana rustica and $N$. glauca) shows that the observed root cellspecific expression of the $\mathrm{HH} 13 \mathrm{~m}$ construct is a reproducible phenomenon not specific to the plant species. It further suggests that the choice of the AUG initiation codon is similar for the translational machinery of these species.

Greenhouse-grown plants display less GUS activity and protein despite similar or higher mRNA levels. It is likely that the in vitro growth in closed containers will induce some stress in the plants, especially in the roots since the plants were grown on agar by which gas exchange for this tissue is limited. Langridge et al. [27] detected more luciferase activity of a mannopine synthase gene fusion with the lux reporter system upon hormone treatment or cutting of the top of the plant. Sanger et al. [45] could show a 60-fold increase of neomycin phosphotransferase (NPT) activity in the young leaves of greenhouse-grown plants after wounding. These treatments also induce stress. We have repeated the cutting experiment of Langridge et al. [27] on in vitro grown plants from three independent offsprings and were unable to find a significant induction of GUS activity. Probably the in vitro grown plants were already 'stress-induced'. The experiments of Sanger et al. [45] were repeated on greenhousegrown plants as described in the Materials and methods section. To exclude as much as possible fluctuations due to the previously described gradient of GUS activity in the plants and to minimize individual fluctuations six transgenic offsprings each consisting of five plants were studied. Harvest and storage of the leaves already led to a 2-4-fold increase within $16 \mathrm{~h}$ of GUS activity per mg extracted protein. Additional wounding of the leaves led to a 1.2- to 2-fold additional increase of GUS. RNA blot analysis did not show higher RNA levels (data not shown). Western blot analysis showed that in two HH10mk progenies the stress (either harvesting, storage or wounding) specifically induced the synthesis of the smaller GUS protein (data not shown).

We want to emphasize here that the ultimate gene expression levels as measured by GUS ac- tivities are not dictated only by the levels of its mRNA and therefore not by its promoter activity. In many publications promoter activities have been studied using gusA, cat or other reporter genes. Often enzyme activity was taken as measurement for promoter activity. Our data clearly show that one has to be very cautious in extrapolating enzyme activities to promoter activities.

Reversing the $35 \mathrm{~S}$ CaMV promoter/hygromycin phosphotransferase gene/nos termination cassette, containing the $35 \mathrm{~S}$ enhancer sequence did not clearly affect GUS activity or RNA levels (Fig. 4, compare lanes 2-4 with 5 and 6). The observed steady-state levels of the HPT transcript varied substantially in the tissues studied (Fig. 5). Observations made by Williamson et al. [53] suggested that the $35 \mathrm{~S} \mathrm{CaMV}$ promoter is not constitutively active but is restricted to actively dividing tissues in whole plants.

We observed in these studies that both the $35 \mathrm{~S}$ CaMV hpt fusion and mannopine synthase gusA fusions are active in Agrobacterium. This is consistent with the findings of DiRita et al. and Gelvin et al. $[10,12]$ who found that fusions between the neomycin phosphotransferase II (npt) gene and the 2' mannopine synthase promoter region lead to resistance in Agrobacterium. Sequences involved in the expression of these genes are therefore not very species-specific.

\section{Acknowledgements}

We thank Norbert Sedee, Ellen P.E. van OsRuygrok and Bram Wetselaar for technical assistance and Ron van Veen for critical reading of the manuscript. This work was supported by a grant from the Rockefeller Foundation.

\section{References}

1. Barker RF, Idler KB, Thompson DV, Kemp JD: Nucleotide sequence of the Agrobacterium tumefaciens octopine Ti plasmid pTi15855. Plant Mol Biol 2: 335-358 (1983).

2. Baulcombe DC, Saunders GR, Bevan N, Mayo A, Harrison $\mathrm{BD}$ : Expression of biological active viral satellite RNA from the nuclear genome of transformed plants. Nature 321: 446-449 (1986). 
3. Benfrey PN, Ren L, Chua N: The CaMV $35 \mathrm{~S}$ enhancer contains at least two domains which can confer different developmental and tissue specific expression patterns. EMBO J 8: 2195-2202 (1989).

4. Bevan M: Binary Agrobacterium vectors for plant transformation. Nucl Acids Res 12: 8711-8721 (1984).

5. Bradford NM: A rapid and sensitive method for the detection of microgram quantities of protein utilizing the principle of protein dye binding. Anal Biochem 72: 753 760 (1976).

6. Cavener DR and Ray SC: Eukaryotic start and stop translation sites. Nucl Acids Res 19: 3185-3192 (1991).

7. Comai L, Moran P and Maslyar D: Novel and useful properties of a chimeric plant promoter combining CaMV 35S and MAS elements. Plant Mol Biol 15: 373-381 (1990).

8. Deblaere R, Bytebier B, De Greve H, Deboeck F, Schell $\mathrm{J}$, Van Montagu M, Leemans J: Efficient octopine Ti plasmid-derived vectors for Agrobacterium mediated gene transfer to plants. Nucl Acids Res 13: 4777-4788 (1985).

9. De Block M, Herrera-Estrella L, Van Montagu M, Schell $\mathrm{J}$, Zambryski P: Expression of foreign genes in regenerated plants and their progeny. EMBO J 3: 681-689 (1984).

10. DiRita VJ, Gelvin SB: Deletion analysis of the mannopine synthase gene promoter in sunflower crown gall tumours and Agrobacterium tumefaciens. Mol Gen Genet 207: 233-241 (1987).

11. Gallie DR, Lucas WL, Walbot V. Visualizing mRNA expression in plant protoplasts: Factors influencing efficient mRNA uptake and translation. Plant Cell 1: 301311 (1989).

12. Gelvin SB, Karcher SJ, Goldsbrough PB: Use of a $T_{R}$ T-DNA promoter to express genes in plants and bacteria. Mol Gen Genet 199: 240-248 (1985).

13. Gheysen G, Villarroel R, Van Montagu M: Illegitimate recombination in plants: a model for T-DNA integration. Genes Devel 5: 287-297 (1991).

14. Gritz L, Davies J: Plasmid encoded hygromycin B resistance: the sequence of hygromycin B phosphotransferase gene and its expression in Escherichia coli and Saccharomyces cerevisae. Gene 25: 179-188 (1983).

15. Hensgens LAM, Van Os-Ruygrok PE: Isolation of RNA and DNA from different rice tissues. Rice Genet Newsl 6: 163-168 (1989).

16. Hoekema A, Hirsch PR, Hooykaas PJJ, Schilperoort RA: A binary plant vector strategy based on separation of Virand T-region of the Agrobacterium tumefaciens Ti plasmid. Nature 303: 179-180 (1983)

17. Hoekema A, Hooykaas PJ, Schilperoort RA: Transfer of the Octopine T-DNA segment to plant cells mediated by different types of Agrobacterium tumour- or root-inducing plasmids: generality of virulence systems. J Bact 158: 383-385 (1984).

18. Hooykaas PJJ, Den Dulk-Ras H, Ooms G, Schilperoort RA: Interactions between octopine and nopaline plas- mids in Agrobacterium tumefaciens. J Bact 143: 12951306 (1980).

19. Jacks T, Varmus HE: Expression of the rous sarcoma virus pol gene by ribosomal frameshifting. Science 230 : 1237-1242 (1985).

20. Jacks T, Power MD, Masiarz FR, Luciw PA, Barr PJ, Varmus HE: Characterization of ribosomal frameshifting in HIV-1 gag-pol expression. Nature 331: 280-283 (1988).

21. Jefferson RA, Burgess SM, Hirsch D: Beta-Glucuronidase from Escherichia coli as a gene-fusion marker. Proc Natl Acad Sci USA 83: 8447-8451 (1986).

22. Jefferson RA, Kavanagh TA, Bevan MW: Gus fusions: beta-glucuronidase as a sensitive and versatile gene fusion marker in higher plants. EMBO J 6: 3901-3907 (1987).

23. Jefferson RA: Assaying chimeric genes in plants: the GUS gene fusion system. Plant Mol Biol Rep 5: 387-405 (1987).

24. Kato T, Shirano Y, Kawazu T, Tada Y, Itoh E, Shibata D: A modified $\beta$-glucuronidase gene: Sensitive detection of plant promoter activities in suspension-cultured cells of tobacco and rice. Plant Mol Biol Rep 9: 333-339 (1991).

25. Kay R, Chan A, Daly M, McPherson J: Duplication of CaMV 35S promoter sequences creates a strong enhancer for plant genes. Science 236: 1299-1302 (1987).

26. Laemmli UK: Cleavage of structural proteins during the assembly of the head of the bacteriophage T4. Nature 227: 680-685 (1970).

27. Langridge WHR, Fitzgerald KJ, Koncz C, Schell J, Szalay AA: Dual promoter of Agrobacterium tumefaciens mannopine synthase genes is regulated by plant growth hormones. Proc Natl Acad Sci USA 86: 3219-3223 (1989).

28. Marsh JL, Erfle M, Wykes EJ. The pIC plasmid and phage vectors with versatile cloning sites for recombinant selection by insertional inactivation. Gene $32: 481-485$ (1984).

29. Meyer EGM, Schilperoort RA, Rueb S, Van Os-Ruygrok PE, Hensgens LAM: Transgenic rice cell lines and plants: expression of transferred chimeric genes. Plant Mol Biol 16: 807-820 (1991).

30. Miller WA, Waterhouse PM, Gerlach WL: Sequence and organization of barley yellow dwarf genomic RNA. Nucl Acids Res 16: 6097-6111 (1988).

31. Morch MD, Drugeon G, Benicourt C: Analysis of the in vitro coding properties of the $3^{\prime}$ region of turnip yellow mosaic virus genomic RNA. Virology 119: 193-198 (1982).

32. Murashige T, Skoog F: A revised medium for rapid growth and bioassays with tobacco tissue cultures. Physiol Plant 15: 473-497 (1962).

33. Nagy F, Odell JT, Morelli G, Chua NH: Properties of expression of the $35 \mathrm{~S}$ promoter from CaMV in transgenic tobacco plants. In: Zaitlin M, Day P, Hollaender A (eds) Biotechnology in Plant Science: Relevance to Agriculture in the Eighties, pp. 227-236, Academic Press, New York (1985). 
34. Odell JT, Nagy F, Chua N-H: Identification of sequences required for activity of the cauliflower mosaic virus $35 \mathrm{~S}$ promoter. Nature 313: 810-812 (1985).

35. Odell JT, Knowlton S, Lin W, Mauvais CJ: Properties of an isolated transcription stimulating sequence derived from the cauliflower mosaic virus $35 \mathrm{~S}$ promoter. Plant Mol Biol 10: 263-272 (1988).

36. Offringa IA, Melchers LS, Regensburg-Tuink AJG, Constantino P, Schilperoort RA, Hooykaas PJJ: Complementation of Agrobacterium tumefaciens tumour-inducing aux mutants by genes from the $\mathrm{T}_{\mathrm{R}}$-region of the $\mathrm{Ri}$ plasmid of Agrobacterium rhizogenes. Proc Natl Acad Sci USA 83: 6935-6939 (1986).

37. Offringa R, de Groot MJA, Haagsman HJ, Does MP, van den Elzen PJM, Hooykaas PJJ: Extrachromosomal homologous recombination and gene targeting in plant cells after Agrobacterium mediated transformation. EMBO J 9: 3077-3084 (1990).

38. Ooms G, Bakker A, Molendijk L, Wullems GJ, Gordon MP, Nester EW, Schilperoort RA: T-DNA organisation in homogeneous and heterogeneous octopine-type crown gall tissues of Nicotiana tabacum. Cell 30: 589-597 (1982).

39. Ow DW, Jacobs JD, Howell SH: Functional regions of the cauliflower mosaic virus 35S RNA promoter determined by use of the firefly luciferase gene as a reporter of promoter activity. Proc Natl Acad Sci USA 84: 48704874 (1987).

40. Pelham HRB: Leaky UAG termination codon in tobacco mosaic virus RNA. Nature 272: 469-471 (1978).

41. Pelham HRB: Translation of tobacco rattle virus RNAs in vitro: Four proteins from three RNAs. Virology 97: 256-265 (1979).

42. Peralta EG, Hellmiss R, Ream W: Overdrive, a T-DNA transmission enhancer on the A. tumefaciens tumour inducing plasmid. EMBO J 5: 1137-1142 (1986).

43. Rueb S, Hensgens LAM: Improved histochemical staining for $\beta$ - $D$-glucuronidase activity in monocotyledonous plants. Rice Genet Newsl 6: 168-169 (1989).

44. Rothstein SJ, Lahners KN, Lotstein RJ, Carozzi NB, Jayne SM, Rice DA: Promoter cassettes, antibioticresistance genes, and vectors for plant transformation. Gene 53: 153-161 (1987).
45. Sanger M, Daubert S, Goodman RM: Characterization of a strong promoter from figwart mosaic virus, comparison with the analogous $35 \mathrm{~S}$ promoter from cauliflower mosaic virus and the regulated mannopine synthase promoter. Plant Mol Biol 14: 433-443 (1990).

46. Schmidhauser TJ, Helinski DR: Regions of broad-hostrange plasmid RK2 involved in replication and stable maintenance in nine species of gram-negative bacteria. $\mathrm{J}$ Bact 164: 446-455 (1985).

47. Teeri TH, Lehvaslaiho H, Frank M, Uotila J, Heino P, Palva ET, Van Montagu M, Herrera-Estrella L: Gene fusions to lac $Z$ reveal new expression patterns of chimeric genes in transgenic plants. EMBO J 8: 343-350 (1989).

48. van den Elzen PJM, Townsend J, Lee KY, Bedbrook JR: A chimeric hygromycin resistance gene as a selectable marker in plant cells. Plant Mol Biol 5: 2723-2730 (1985).

49. van Haaren MJJ, Sedee NJA, de Boer HA, Schilperoort RA, Hooykaas PJJ: Mutational analysis of the conserved domains of a T-region border repeat of Agrobacterium tumefaciens. Plant Mol Biol 13: 523-531 (1989).

50. Veidt I, Lot H, Leiser H, Scheidecker D, Guilley H, Richards K, Jonard G: Nucleotide sequence of beet western yellows virus RNA. Nucl Acids Res 16: 9917-9932 (1988).

51. Velten J, Velten L, Hain R, Schell J: Isolation of a dual plant promoter fragment from the $\mathrm{Ti}$ plasmid of Agrobacterium tumefaciens. EMBO J 3: 2723-2730 (1984).

52. Velten J, Schell J: Selection-expression plasmid vectors for use in genetic transformation of higher plants. Nucl Acid Res 13: 6981-6998 (1985).

53. Williamson JD, Hirsch-Wyncott ME, Larkins BA, Gelvin SB. Differential accumulation of a transcript driven by the CaMV $35 \mathrm{~S}$ promoter in transgenic tobacco. Plant Physiol 90: 1570-1576 (1989).

54. Xiong Z, Lommel SA: The complete nucleotide sequence and genome organization of red clover necrotic mosaic virus RNA-1. Virology 171: 543-554 (1989).

55. Ziegler V, Richards K, Guilley H, Jonard G, Putz C: Cell-free translation of beet necrotic yellow vein virus: Readthrough of the coat protein cistron. J Gen Virol 66: 2079-2087 (1985). 